\title{
The Revenge of Mullaney v. Wilbur: U.S. v. Booker and The Reassertion of Judicial Limits on Legislative Power to Define Crimes
}

\author{
by Ian Weinstein ${ }^{*}$
}

Since the end of World War II, our Constitutional law of criminal sentencing has veered from judicial sentencing supremacy to legislative domination and back again. In 1949, the Court gave us a paean to judicial sentencing discretion, Williams v. New York.. ${ }^{1}$ In the mid 1970s it began to develop a set of doctrines that abetted the construction of a legislative straitjacket on judicial sentencing power. Turning rather suddenly after more than 20 years on the road of legislative dominance, the Court cut those ties, freeing judges to sentence as they may and rejecting the most important set of legislative sentencing reforms of the last century in a set of cases culminating with Booker v. United States. ${ }^{2}$ Viewed as cases regulating sentencing, it is hard to see a consistent logical thread running through these cases. But ours is a criminal justice

* Professor of Law, Fordham University School of Law. I presented an earlier draft of this paper at The Association of the Bar of the City of New York. I want to thank my research assistant, Ms. Marissa Kay, for her outstanding work on this paper.

${ }^{1} 337$ U.S. 241 (1949) (affirming judicial imposition of a death sentence based on evidence not presented to the jury and found by the judge by a preponderance of the evidence).

${ }^{2} 125$ S. Ct. 738 (2005) (excising the portions of the Federal Sentencing Guidelines that made them binding to remedy a violation of the Sixth Amendment right to a jury trial). 
system of fragmented power and indirect regulation, in which cases about one thing may really be directed at quite another.

For example, we regulate the jury trial right not so much to control the rare jury trial, but more to influence the balance of forces that will determine the negotiated pleas that will resolve most cases. ${ }^{3}$ Although doctrine is an important constraint, our criminal justice system retains the distinctive Anglo-American preference for a high degree of indirect regulation of relatively unconstrained individual official actors with competing spheres of authority. ${ }^{4}$ The criminal law,

${ }^{3}$ Stephanos Bibas, Plea Bargaining Outside the Shadow of Trial, 117 HARV. L. REV. 2463 (2004) (arguing that structural influences and psychological factors make the results of the current plea bargaining regime diverge dramatically from those that would be achieved under a system in which trials predominated or under a system of reformed plea bargaining system); William J. Stuntz, Plea Bargaining and Criminal Law's Disappearing Shadow, 117 HARV. L. REV. 2548 (2004) (arguing that as the criminal law expands, it imposes fewer constraints on plea bargains).

The Supreme Court has recognized that regulation of the Sixth Amendment right to trial shifts the allocation of power among prosecutors, judges and defendants, changing the dynamics of plea bargaining. However, while the majority and dissenters agree that power shifts as the contours of the trial right change, they disagree on who will gain power, who will lose power and whether the shifts will help or harm most defendants. Washington v. Blakely, 125 S.Ct. 21 (2004).

Of course, the details of the Sixth Amendment right also matters a great deal to those defendants who choose to go to trial. The changes in sentencing law and procedure discussed in this article have also diminished the power of the juries in the cases they decide. Rachel E. Barkow, Recharging the Jury: The Criminal Jury's Constitutional Role in an Era of Mandatory Sentencing, 152 U. PA. L. REV. 33 (2003) (arguing that mandatory sentencing regimes have diminished the power of the criminal jury).

${ }^{4}$ Professor Daniel C. Richman has noted the tendency to checks and balances even within the law enforcement establishment itself. "After all, the entire American criminal justice system is characterized by an almost instinctive embrace of fragmented authority, with the tensions between police and prosecutors, attorneys general and district attorneys seen as a virtue, rather than a vice." Daniel C. Richman, Federal Criminal Law, Congressional Delegation, and Enforcement Discretion, 46 UCLA L. REV. 757, 807 (1999) (arguing that Congress exercises greater control over federal law enforcement through funding, oversight hearings and other bureaucratic mechanisms than by limiting or tailoring substantive statutes, but these controls only work in some areas of enforcement and tend to be motivated less by policy preferences and 
which is arguably our most public exercise of legal power, retains a strong flavor of market style regulation. Public actors, such as prosecutors and judges, exercise public authority while retaining a significant degree of individual discretion through doctrines of non-review ${ }^{5}$ or review under standards which insulate all but the most outrageous decisions from reversal. ${ }^{6}$

This paper argues that the modern sentencing procedure cases make more sense when understood as the Court's best effort to maintain balance among judges, prosecutors and legislators in the face of changing political and social conditions. Although the cases regulate sentencing, they use sentencing as a means to a larger end as they address narrower doctrinal

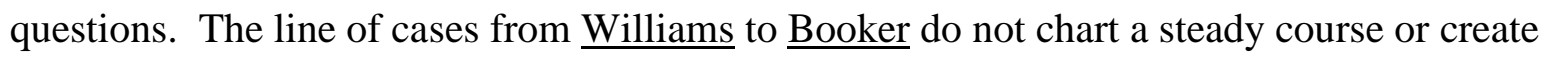

more by the desire to curb executive power).

${ }^{5}$ Prosecutorial decisions about when or what to charge are virtually unreviewable. The Supreme Court has noted that in the ordinary case, "so long as the prosecutor has probable cause to believe that the accused committed an offense defined by statute, the decision whether or not to prosecute, and what charge to file or bring before a grand jury, generally rests entirely in his discretion." Bordenkircher v. Hayes, 434 U.S. 357, 364 (1978) (holding that although petitioner was originally indicted for uttering a forged instrument, due process was not violated when, during the course of plea negotiations, the prosecutor threatened to seek an indictment under Habitual Criminal Act if petitioner did not plead guilty to the forged instrument charge). See also United States v. Armstrong, 517 U.S. 456, 463 (1996) (holding that discovery on a selective prosecution claim is only required after a threshold showing that others of a different race who were otherwise similarly situated were not prosecuted). For the American historical background of prosecutorial discretion, see, Carolyn B. Ramsey, The Discretionary Power of "Public" Prosecutors in Historical Perspective, 39 AM. CRIM. L. REV. 1309, (2002) (arguing that the shift from private to public prosecutors was driven by a desire to make crime control more efficient, not to exercise greater public control and make the criminal law more accountable to law).

${ }^{6}$ Under the Federal Sentencing Guidelines' regime, for example, departure review under the abuse of discretion standard insulated trial judges in many circuits from reversal, freeing them to push the boundaries of the law. See Ian Weinstein, The Discontinuous Tradition of Sentencing Discretion: Koon's Failure to Recognize the Reshaping of Judicial Discretion under the Guidelines, 79 B.U.L. REV. 493 (1999) (finding that some of the circuits reversed virtually no district court departures under the abuse of discretion standard). Many question whether reasonableness review in the current regime will have any teeth. 
optimal sentencing doctrines; they indirectly regulate the entire criminal justice system as they directly address sentencing.

The big issue behind these cases is the allocation of authority in American criminal law among trial judges, appellate judges, prosecutors and legislators. In the late 1970s, at a time when the sphere of legislative action in the criminal area seemed well defined by practice, the Court curtailed judicial review of the legislature's power to define crimes and set punishments. It was safer to give power to bodies that seemed disinclined to use it aggressively than to trust power to judges who appeared inclined to use it. But by the late 1990s, legislators had clearly demonstrated their willingness to exercise their power over criminal justice issues at the limits the Court had set for them. They also made it clear that they had come to understand that their interests were strongly tied to those of prosecutors, and both branches gained power as judges lost it. ${ }^{7}$ So, as the public clamor for severe penal laws began to abate a little, the Court began to push back in the late 1990s. In an effort to rebalance the system, the Court reallocated power

${ }^{7}$ Congress and many state legislatures have used their greater power to define crimes and punishments to transfer power from judges to prosecutors by passing mandatory minimum sentencing statutes and other kinds of detailed criminal provisions that strengthen the prosecutor's position in plea bargaining. See William J. Stuntz, The Pathological Politics of Criminal Law, 100 MiCH. L. Rev. 505, 537-40 (2001) (discussing how overcriminalization expands prosecutorial power and noting the alliance that developed between legislators and prosecutors in the late $20^{\text {th }}$ Century); Ian Weinstein, Fifteen Years After the Federal Sentencing Revolution: How Mandatory Minimums Have Undermined Effective and Just Narcotics Sentencing, 40 AM. CRIM. L. REV. 87, 108-12 (2003) (offering an example of how the addition of new, more specific federal narcotics crimes and changes in sentencing law shifted power to prosecutors in the period from 1985 to 2000). But even the relationship between the adoption of detailed criminal statutes and increased prosecutorial power depends upon and can be altered by changes in a variety of sentencing procedures. Thus, all things being equal, greater statutory specificity increases prosecutorial bargaining leverage, except where judges retain broad sentencing discretion, where statutory sentencing ranges have significant overlap, where caseload pressure and local culture result in lenient plea offers or where any number of other factors may counterbalance the impact of greater statutory specificity. It is a complex and uncertain business in which all things are rarely equal. 
from the legislators and prosecutors to the judges. It bears noting that the current arrangements may be overturned by Congress and the state legislatures affected by these changes. It remains to be seen whether we are at, or will come to, a period of stability in our sentencing law and practices.

\section{The Historical, Doctrinal and Practice Context of Our Constitutional Sentencing Law}

There was much less criminal law in America fifty years ago. There were fewer criminal statutes and they were generally shorter, simpler and less specific than many recent enactments. Statutes tended to codify the long standing common law definitions of crimes and within that tradition, states were free to criminalize conduct as each saw fit. Criminal procedure law was generally found in the cases, not statutes. It was less technically demanding and not yet constitutionalized. Beyond the most basic procedural requirements, such as jury trials for felonies, states enforced their laws in a variety of ways with very little oversight or intervention by courts or legislatures. ${ }^{8}$

American criminal law has grown larger and more complex in the last fifty years and its focus has shifted toward procedure. There has been a great wave of re-codification. Many state systems have moved far from the common law tradition and significantly towards more detailed

\footnotetext{
${ }^{8}$ Of course, it can also be said that there was much more criminal law in America in 1949 than there was in 1900. The rise of national markets, the emergence of the Progressive era proto regulatory state, the New Deal and most importantly, Prohibition, all sparked waves of new criminal statutes, new enforcement techniques and expansion of the federal role in criminal law and criminal enforcement. Waves of federalization of criminal law have characterized American criminal justice since the Fugitive Slave Act and the Civil War caused the first stirrings of the idea of a national American criminal law.
} 
and specific criminal statutes. ${ }^{9}$ As the Supreme Court has constitutionalized criminal procedure, federal law enforcement and federal adjudication of criminal cases has grown tremendously. ${ }^{10}$ Along with a new level of complexity, we have greater national consistency in our criminal law and practice than we had in 1955. Yet, great variation in substantive law, procedure and practice remains a signal feature of American criminal law, given the diverse systems in place in the fifty states, the District of Columbia, the federal and the military courts. ${ }^{11}$

Along with all of the variation, there are also unifying themes in American criminal justice. From the end of World War II through about 1980, the everyday practice of criminal law in American courts was strongly influenced by the rehabilitative ${ }^{12}$ theory of punishment, ${ }^{13}$ and

${ }^{9}$ See generally William J. Stuntz, The Pathological Politics of Criminal Law, $100 \mathrm{MICH}$. L. REV. 505, 515-20 (2001) (describing the growth of criminal law in America).

${ }^{10}$ See Sara Sun Beale, What's Law Got To Do With It? The Political, Social, Psychological And Other Non-Legal Factors Influencing The Development Of (Federal) Criminal Law, 1 BUFF. CRIM. L. Rev. 23 (1997) (examining whether the politicizing of crime causing an emphasis on harsher sentences is the right direction for this country).

${ }^{11}$ Looking across the varied landscape of American criminal justice, one can find current examples of criminal sentencing in America that are characterized by unfettered judicial discretion, complete legislative control through mandatory sentencing, jury sentencing or enforceable guideline sentencing, as well as a range of combinations of each variety of sentencing. Perhaps more importantly, very few of these doctrines address, and none control, the process of plea bargaining, through which we resolve the vast bulk of criminal cases. Finding guiding historical principles and developing and enforcing useful general rules for this wide variety of doctrines and practices is a central problem in American sentencing law. Even if we had useful general principles, we would still find ourselves committed to an odd sort of semiregulated marketplace at the core of the whole enterprise.

${ }^{12}$ The rehabilitative, or correctionalist, theory aims to reform the criminal so that he or she will not reoffend. For an early European proponent of rehabilitation, see CESARE BECCARIA, ON CRIME AND PUNISHMENT, first published in 1764. The rehabilitative movement took root in Victorian England and soon came to America. See Norval Morris AND DAVID J. Rothman, The OXFord History OF THE PRISON: The Practice OF PUNISHMENT IN WESTERN SOCIETY (1995). In Michael Foucault's book, DisCIPLINE AND PUNISH: THE BIRTH OF THE PRISON, (1997) he offers the classic theoretical treatment of the deep social roots of the rehabilitative idea in the development of modern society. For a trenchant application of Foucault's ideas to American 
the doctrines and practices furthering that goal in a concrete way. ${ }^{14}$ This story begins early in that era, with Williams v. New York, a 1949 case that affirmed the power of sentencing judges to consider a wide range of evidence and use informal procedures at sentencing. These very flexible procedures made sense in the era of rehabilitative sentencing when judges imposed indeterminate terms for the purpose of reforming the individual who stood before the court. Every sentence was a fresh creative and interpretative act with the goal of finding the correct approach to this unique defendant and his or her problems and challenges.

Also, from the mid 1950s through the late 1970s, the American justice system made an effort to bring the whole nation, particularly the South, into the modern era by ending institutionalized racism and moderating excessive punishment through court driven procedural reform. Legislative interest in criminal law focused upon the substantive criminal law, as many states participated in the great wave of Model Penal Code inspired re-codification. ${ }^{15}$ The criminal justice since World War II, see David Garland, The Culture of Control (2001).

${ }^{13}$ Professor Douglas Berman has insightfully argued that these cases must be understood in light of the shift from rehabilitation to retribution as the dominant justification for criminal sanction. Douglas A. Berman, The Roots and Realities of Blakely, 19 CRIMINAL

Justice 5 (2005).

${ }^{14}$ For a description of how the shift from the rehabilitative ideal and unfettered judicial sentencing discretion to a system of retributive sentencing using enforceable sentencing guidelines dramatically changed the power dynamics among judges, prosecutors and defense lawyers and radically shifted the day to day practice of criminal law, see Weinstein, Fifteen Years after the Revolution, supra note 7 at 101.

${ }^{15}$ Herbert Wechsler, Forward to Model Penal Code and Commentaries at xi (The American Law Institute 1985) (noting that by 1982, 20 years after the introduction of the Model Penal Code in 1962, more than two thirds of the states had recodified their criminal laws using the Model Penal Code as a starting point). Congress joined the effort, but was unable to agree on a recodification of the Federal Criminal Code, which retains many older common law based statutes, despite having swelled with a plethora of more modern additions. See Gerard E. Lynch Towards A Model Penal Code, Second (Federal?): The Challenge of the Special Part 2 BufF. CRIM. L. Rev. 297, 315-16 (1998). 
legislative focus on rehabilitative sentencing and implementing the substantive criminal law provisions of the Model Penal Code was consistent with both the rehabilitative ideal, ${ }^{16}$ and the Supreme Court driven constitutionalization of criminal procedure law in investigation and adjudication. $^{17}$

The strains in our continued devotion to both rehabilitation and the procedural revolution were evident by the early 1970s, but criticism of both trends became dominant by the mid 1980s. As David Garland has argued so trenchantly, during this period, a real rise in crime rates caused by changes in both family and work life coupled with the political upheavals of the late 1960s and changes in the way the media covered crime combined to re-politicize crime in America. ${ }^{18}$ By the mid 1970s, crime was on the agenda of most politicians and it had become standard fare

\footnotetext{
${ }^{16}$ The drafters of the Model Penal Code were strongly influenced by psychological ideas quite sympathetic to the rehabilitative ideal. My colleague, Professor Deborah Denno, has explored their strong Freudian bent. See Deborah W. Denno, Crime and Consciousness: Science and Involuntary Acts, 87 MiNN. L. REV. 269 (2002). I am not arguing that only Freudian pscychology is consistent with rehabilitation, but rather that like many other thinkers of that period, Wechsler and others were strongly influenced by psychology in their thinking about both substantive criminal law and penal theory. This approach lends itself to treating crime as a pathology that may be cured, as opposed, for example, to an approach influenced more by economics, consequently viewing crime as an undesirable behavior to which a significant cost should be attached.

${ }^{17}$ In addition to their shared intellectual roots in Post World War II American modernism, these trends fit together in a functional way. They permitted the different criminal justice actors to focused on their own realms. Thus, legislatures focused on the substantive law of crimes in this period and, following the lead of the Model Penal Code drafters, did not address the law of sentencing or sentencing procedures to any significant degree. Trial judges, particularly in the federal system, exercised virtually unreviewable authority over sentencing, while the appellate courts focused on regulating investigation and adjudication. The executive, which was beginning to appreciate the possibilities of an expanded enforcement regime by the end of this period, continued to roam the wide field defined by the expansive Anglo-American principle of prosecutorial discretion.

${ }^{18}$ David GARland, The CUlture of CONTROL: CRIME AND SOCIAL ORdER IN CONTEMPORARY SocIETy, Chapter 4 (University of Chicago Press 2001). See also Rachel E. Barkow, Administering Crime, 52 UCLA L. Rev. 715, n. 94 (2005).
} 
to criticize the courts for coddling criminals and letting them go on "technicalities." The rehabilitative ideal, an idea that had dominated penal theory for many years, collapsed suddenly. ${ }^{19}$ America was well on its to what has become widely recognized as the politicization of crime and the one way ratchet in which criminal justice legislation only begets more penal law imposing even harsher sentences. ${ }^{20}$

The shift from the era of rehabilitation and relatively less political focus on crime to the era of retributivism, ${ }^{21}$ or modified just deserts ${ }^{22}$ and keen political interest in criminal justice provides the contextual key to understanding the Supreme Court's dramatic doctrinal shifts on the permissible scope of judicially imposed limits on legislative drafting of criminal statutes. By

${ }^{19} I d$. at Chapter 3 (describing and analyzing the sudden collapse of the rehabilitative ideal in the late 1970s).

${ }^{20}$ See Beale, supra note 10.

${ }^{21}$ Retributivism, or just deserts, holds that moral blameworthiness is a sufficient justification for punishment, aside from any consequentialist justification. It has an ancient lineage, often traced back to the Biblical 'eye for an eye,' formula. Immanuel Kant offered a retributivist justification of the criminal sanction in The Philosophy of Law. An outstanding contemporary work on retributivism and related ideas is JEFFRIE G. MURPHY \& JEAN HAMPTON, FORGIVENESS AND MERCY (Cambridge University Press 1990).

${ }^{22}$ Modified just deserts is a theory of punishment that views retributivism through the lens of proportionality and tempers it with a strong dose of specific deterrence or incapacitation. Thus, it views moral blameworthiness as the prime reason for punishment, emphasizes escalating punishment as the offender's conduct grows more blameworthy and gives relatively great weight to the likelihood that a particular offender will re-offend as a sufficient reason to increase punishment. It subordinates considerations of rehabilitation and general deterrence in sentencing. It is the theory that best explains the Federal Sentencing Guidelines. See Paul J. Hofer \& Mark H. Allenbaugh, The Reason Behind the Rules: Finding and Using the Philosophy of the Federal Sentencing Guidelines, 40 AM. CRIM. L. REV. 19, 51-54 (2003). More broadly, modified just deserts is quite congenial to the social forces that have moved toward more severe criminal sanctions over the past 25 years. See generally, Joseph E. Kennedy, Monstrous Offenders and the Search for Solidarity Through Modern Punishment, 51 Hastings L.J. 829 (2000); Jonathan Simon, Sanctioning Government: Explaining America's Severity Revolution, 56 U. MiAmi L. REV. 217 (2001). 
the time one of the central and most cited cases in this line, Pennsylvania v. McMillan, came to the Court in 1986, much had changed from the era of Williams. America had experienced a real rise in serious crime over the 20 years from 1960 to 1980 . Crime had become an issue on every politician's agenda; the rehabilitative model had been replaced by a punitive form of retributivism ${ }^{23}$; and a larger political realignment had empowered critics of the old school of criminal justice. Almost nothing could be heard over the full throated political roar favoring harsher sentences. At the same time, but for different political reasons, the imperial federal judiciary of the 60s and 70s was under political attack and majoritarianism was on the rise. In the midst of what seemed like a broad political consensus, the Court went down the road of unfettered legislative discretion to define crimes with almost no judicial oversight.

Of course, the re-emergence of crime as a hot button political issue was just one piece of a larger dynamic of shifting intellectual, sociological and economic forces during the second half of the twentieth century. Changing patterns of criminality driven by new social patterns and urbanization, ${ }^{24}$ the civil rights struggle, America's shifting religious landscape and more

${ }^{23}$ Increasing sentence severity became an explicit goal of the sentencing reform movement. See Kate Stith \& Steve Y. Koh, The Politics of Sentencing Reform: The Legislative History of the Federal Sentencing Guidelines, 28 WAKE FOREST L. REV. 223, 284-87 (1993). Federal sentences grew much harsher in the early 1990s as the Guidelines and a range of mandatory minimum sentencing statutes took hold. See Paul J. Hofer \& Courtney Semisch, Examining Changes in Federal Sentencing Severity: 1980-1998, 10 FED. SENT. R. 12 (1999). Many states made similar legal changes starting in the mid 80s and experienced similar sentencing trends from the late 80 s through the late $90 \mathrm{~s}$. For a definitive analysis of these trends in federal narcotics sentencing, which accounts for $40 \%$ of the federal criminal docket and is at the core of many of the changes in American criminal law over the past 30 years, see Frank Bowman and Michael Heise, Quiet Rebellion II: An Empirical Analysis of Declining Federal Drug Sentences Including Data from the District Level, 87 IOWA L. REV. 477 (2002).

${ }^{24}$ See Garland, supra note 18 at 162. 
recently, changes in policing strategies ${ }^{25}$ and technology, ${ }^{26}$ as well as the rise of terrorism as a defining security and criminal law issue of our time,${ }^{27}$ have all shaped our current attitudes toward criminal justice. In broad stroke, the criminal law and criminal procedure doctrines I examine here were buffeted by a real rise and then fall in crime, ${ }^{28}$ a significant shift in ideas of

${ }^{25}$ The best known example of this new style of policing, sometimes called 'public order policing,' is often associated with the Broken Windows theory first put forward by James Q. Wilson. The theory emphasizes vigorous enforcement of minor offenses. James Q. Wilson \& George L. Kelling, Broken Windows: The Police and Neighborhood Safety, ATLANTIC Monthly, Mar. 1982, at 29. New York City Police Commissioner William Bratton adopted Wilson and Kelling's Broken Windows' thesis as the basis for the city's new policing initiative in 1994. City of New York, Police DeP' t, Police Strategy No. 5: Reclaiming the Public SPACES OF New YorK (1994) (setting forth the New York City Police Department's strategy for improving disorderly conditions); see also William J. Bratton, Policy Review: The New York City Police Department's Civil Enforcement of Quality-of-Life Crimes, 3 J. L. \& POL'y 447, 447-51 (1995). As practiced by Bratton, head of New York's Transit Police, Mayor Giuliani's Police Commissioner and now the head of the Los Angeles Police Department, this style of policing includes: (1) an evidence based or data driven strategy (i.e. extensive use of information technology to identify crimes patterns and develop statistically driven assessments of police techniques); (2) a high contact strategy (in which the police seek to interact with as many minor offenders as possible to maximize the number of searches and warrant checks performed); and (3) flooding the zone (saturation policing which involves using the statistics generated by information technology to target particular neighborhoods for intensive police activity). The link between aggressive enforcement of minor offenses in targeted neighborhoods and a decrease in crime is far from clear, but the decrease in crime appears real. See Bernard E. Harcourt, Reflecting on the Subject: A Critique of the Social Influence Conception of Deterrence, the Broken Windows Theory, and Order-Maintenance Policing New York Style, 97 MicH. L. REV. 291, 293-93, 377-81 (1998); Ana Joanes, Does the New York City Police Department Deserve Credit for the Decline in New York City's Homicide Rates? A Cross-City Comparison of Policing Strategies and Homicide Rates, 33 ColuM. J.L. \& SoC. ProbS. 265, 274-81 (2000).

${ }^{26}$ See Garland, supra note 18 at 160-63.

${ }^{27}$ See Daniel C. Richman \& William J. Stuntz, Al Capone's Revenge: An Essay on the Political Economy of Pretextual Prosecution, 105 COLuM. L. REV. 583 (2005) (arguing that the rise of terrorism as a criminal justice concern creates new incentives for prosecutors to use the problematic tool of pretextual prosecution).

${ }^{28}$ Although, perceptions of crime continued to rise. See Beale, supra note 10 at 47-54. As well, salient events like the crack epidemic of the late 80s continued to feed the perception of spiraling disorder. 
personal responsibility, a cycling of power away from and perhaps back to courts, and the emergence of new threats and new methods of detection, enforcement and proof.

As is often the case, society began to change before politicians or the law recognized it. As people began to adjust to falling crime rates, new technology and old political concerns whetted the public appetite for stories of wrongful convictions and police misconduct. In the shifting criminal justice sands of the turn of the $21^{\text {st }}$ Century, the Court seized the opportunity to push back against legislative dominance in the criminal arena, motivated by a combination of institutional imperative, congruent individual views on how the Constitution should be read ${ }^{29}$ and perhaps the view that severity had gone too far. It did not make for pellucid doctrine, but it is an example of how we regulate American criminal justice by recalibrating the relationships among the several players who share and balance power in our criminal justice system.

\section{The Modern Jurisprudence Begins with Williams v. New York and Broad Judicial}

\section{Discretion}

The modern American constitutional procedural law of sentencing ${ }^{30}$ begins with

\footnotetext{
${ }^{29}$ Perhaps this is only an obscure way of saying that there is no really satisfying explanation for how Justice Scalia came round to a position for which Justice Stevens had long argued.

${ }^{30}$ The Supreme Court's sentencing jurisprudence has been largely procedural. Substantive appellate review of federal sentencing did not exist before the Sentencing Reform Act and the Sentencing Guidelines. See United States v. Tucker, 404 U.S. 443, 447 (1972); Dorszynski v. United States, 418 U.S. 424, 431 (1974). The development of the doctrine of nonreviewability and its weakening through increasing procedural scrutiny of federal sentencing by courts of appeal is discussed in Robert J. Kutak and J. Michael Gottschalk, In Search of a Rational Sentence: A Return to the Concept of Appellate Review, 53 NEB. L. REV. 463 (1974) (demonstrating convincingly that courts of appeal occasionally used procedural dress to remand egregious sentences, but arguing for appellate review because the doctrine of non-reviewability 
$\underline{\text { Williams v. New York }}{ }^{31}$ a case that clearly captures the post World War II faith in expertise and the power of psychology and social work. The Supreme Court's first look at sentencing in the modern era reflects the solid grasp of rehabilitation as the dominant penal theory of this period.

Samuel Williams was convicted of murder. The jury recommended a sentence of life in prison. The trial judge sentenced him to death, relying upon facts contained in a pre-sentence report. The defendant argued that he was entitled to confront the witnesses against him at the sentencing hearing, but the Supreme Court upheld the sentence. The Court ruled that the defendant's sentencing was properly governed by much more relaxed rules of procedure than those governing trial. The Court drew a bright line rule between the jury role in adjudicating guilt or innocence and the judicial role in fashioning an individualized sentence in the era of indeterminate, rehabilitative sentencing.

Although Williams is no longer good death penalty law, it is still cited for the proposition that there is a well settled American legal practice history of sentencing judges exercising discretion about both the mechanics of sentencing and the nature of the sentence imposed. ${ }^{32}$ The

prevented the development of sentencing standards). Although the Federal Sentencing Guidelines offered an opportunity for the Court to develop a substantive law of sentencing, its shrinking docket did not address those issues, displaying a continued preference for procedural cases such as Koon.

More fundamentally, a very weak doctrine of proportionality review is a rejection of the most likely Constitutional basis for broad, substantive regulation of criminal sentencing and undergirds the significant authority Congress and each state legislature maintains over the substantive law of sentencing. See Solem v. Helm, 463 U.S. 277 (1983); Ewing v. California, 538 U.S. 11 (2003) (rejecting a challenge to California's three strikes law. A current and very useful reassessment of this area is, Youngjae Lee, The Constitutional Right Against Excessive Punishment, 91 VIRGINIA LAW REVIEW (forthcoming May 2005).

${ }^{31}$ See Williams, supra note 1.

${ }^{32}$ Apprendi v. New Jersey, 530 U.S. 466, 481 (2000) (noting that "judges in this country have long exercised discretion of this nature in imposing sentence within statutory limits in the -13- 
Supreme Court endorsed a flexible set of sentencing procedures in Williams, noting that the ultimate aim was for the judge to impose a proper, individualized sentence that would promote rehabilitation. That goal, seen through the lens of the reigning psychological and social service understanding of the day, was inherently individualistic. The judge needed to understand enough about this individual to impose a sentence that held out the hope of reforming him or her. This is not a sentencing regime built primarily upon concerns about uniformity and retribution. ${ }^{33}$

The Williams Court reminded us that sentencing procedures would remain subject to due process scrutiny, citing Townsend v. Burke. ${ }^{34}$ However, the egregious facts of Townsend, involving an obvious factual mistake by the sentencing judge in a case involving an uncounseled defendant, suggest just how undemanding that scrutiny would be. Williams and its progeny, including Brady v. Maryland ${ }^{35}$ and United States v. Grayson ${ }^{36}$ established that individualized,

individual case"). See, e.g., Williams, 337 U.S. at 246 (discussing that "[b]oth before and since the American colonies became a nation, courts in this country and in England practiced a policy under which a sentencing judge could exercise a wide discretion in the sources and types of evidence used to assist him in determining the kind and extent of punishment to be imposed within limits fixed by law").

${ }^{33}$ In the American view of rehabilitative sentencing, the judge must figure out how to shape the sentence to address the particular psychological and social issues that lead this individual to make bad choices. Although this is a strong and longstanding connection in our law and reflects our criminal law's deep commitment to individual will and autonomy, it is a connection contingent upon our particular view of autonomy and choice. Rehabilitation may be very differently conceived. Political reeducation, as practiced by other regimes, suggests how rehabilitation can be understood as a standardized group practice rather than an individualized one.

${ }^{34} 334$ U.S. 736 (1948) (granting relief to an un-counseled defendant whose sentence was enhanced based on the sentencing court's erroneous belief that the defendant had been convicted of certain offenses, when in fact it was the defendant's brother who had been convicted of those crimes).

${ }^{35} 373$ U.S. 83 (1963) (requiring prosecutors to disclose exculpatory material to the defense). 
rehabilitative sentencing was governed by much less demanding procedural requirements than trial.

Williams reflected the longstanding understanding of the division of authority between the judge and jury. The line between guilt and innocence remained the province of the jury, with all of the strong procedural protections afforded by the Constitution. Once a defendant was found guilty, punishment was generally the province of the judge. ${ }^{37}$ The key was, and remains, drawing the line at which the Sixth Amendment jury trial right attaches, along with the requirement of proof beyond a reasonable doubt. The contours of the procedural rights due at sentencing have long been anchored at the line between the elements of the offense, ${ }^{38}$ which must go to the jury, and other factors relevant to sentencing, which need not be adjudicated by the jury and may be determined in a less formal procedure.

\section{The Central Question Emerges in Mullaney and Patterson: What is an Element?}

In the modern era of criminal jurisprudence, the Supreme Court began to draw the line between the demanding Sixth Amendment jury trial right and the less demanding Due Process

${ }^{36} 438$ U.S. 41 (1978) (affirming a sentence enhanced by a judicial finding that the defendant had lied during his trial testimony).

${ }^{37}$ While this had long been true in England, the federal system and much of America, some American states have long used jury sentencing. See generally Jenia Iontcheva, Jury Sentencing as Democratic Practice, 89 VA. L. Rev. 311 (2003) (noting that six states employ jury sentencing in non-capital cases and arguing for its expansion in light of Apprendi).

${ }^{38}$ For an outstanding current discussion of the history and difficulties of the elements test, see Stephanos Bibas, Judicial Fact-Finding and Sentence Enhancements in a World of Guilty Pleas, 110 YALE L. J. 1097 (2001) (arguing that the strong form of the elements test adopted by the Supreme Court has weak historical roots, that the rules are responsive to problems that modern criminal law no longer faces, and that the elements test does not address the issues presented by our plea bargaining regime). 
right to a fair sentencing procedure in Mullaney v. Wilbur, ${ }^{39}$ and Patterson v. New York. ${ }^{40}$ This very important and hard to reconcile pair of cases examines what consequences flow from the broad state power, exercised primarily by the legislature, to define crimes and determine the punishment attendant upon conviction. Although neither case involves a direct challenge to a sentence or sentencing procedure, in our system of indirect regulation of the dominant guilty plea regime, the cases loom large in the sentencing landscape.

In Mullaney, the Court affirmed the grant of a writ of habeas corpus to Stillman E. Wilbur, Jr., who had been convicted of first degree murder in Maine. Maine's common law based first degree murder statute included the traditional mens rea requirement of malice aforethought. $^{41}$ The wrinkle in Maine law was that for many years, proof of an intentional, unlawful killing gave rise to a rebuttable presumption of malice aforethought. Once the presumption was invoked, the defendant could then prove, by a fair preponderance of the evidence, that he acted on sudden provocation, which reduced the crime to manslaughter. ${ }^{42}$ Relying on In Re Winship, ${ }^{43}$ the Court focused on the historical significance of the line between murder and manslaughter and held that the state must bear the burden of proof, and prove
${ }^{39} 421$ U.S. 684 (1975).
40432 U.S. 197 (1977).

${ }^{41}$ Malice aforethought is the term of art for the mens rea required for murder under the common law. Generally, malice aforethought includes all killings that i) were intentional, ii) resulted from acts done with the intent to inflict grievous bodily injury, iii) resulted from acts done with extremely reckless disregard for human life, or iv) resulted from the commission of, or from the flight from, a felony. See generally JoshUA DRESSLER, UNDERSTANDING CRIMINAL LAW §32.01 (Lexis Publishing 2001).

${ }^{42}$ Heat of passion, or passion and provocation, is the common law doctrine that reduces murder to manslaughter if the defendant acted in the heat of passion resulting from adequate provocation without a sufficient lapse of time for the passion to cool. Id. at \$31.07[B][1].

${ }^{43} 397$ U.S. 358 (1970). 
beyond a reasonable doubt the issue of the absence of provocation.

Although Mullaney struck a blow against unfettered state power to define crimes, this opening salvo, in what became a lengthy and complex campaign, was very carefully aimed. The defendant initially challenged his conviction in the Maine state courts, arguing that the statute created two separate crimes, with separate elements that must be proven by the prosecution. The Maine Supreme Judicial Court ruled that the statute created only one crime, felonious homicide, with two different degrees. The lower federal courts ${ }^{44}$ disagreed with the State Court's reading of the Maine statute and adopted the petitioner's two crimes approach. The United States Supreme Court affirmed the lower courts' result, but rejected their reinterpretation of Maine law. ${ }^{45}$

The Court ruled that the state courts are ultimate expositors of state law, ${ }^{46}$ and accepted the Maine Supreme Judicial Court's view that the Maine statute created one crime, with two distinct degrees. The Court went on to frame the issue in terms of the burden of proof, questioning whether "the Maine rule requiring the defendant to prove that he acted in the heat of

${ }^{44}$ See Wilbur v. Robbins, 349 F.Supp. 149 (S.D. Me. 1972); Wilbur v. Mullaney, 473 F.2d $943\left(1^{\text {st }}\right.$ Cir. 1973).

${ }^{45} 421$ U.S. 684 (1975). The picture was a bit more complex. After this case was decided by the First Circuit, the Maine Supreme Court reaffirmed its view that the Maine statute created only one crime with two different degrees and sharply criticized the First Circuit's view of state law, State v. Lafferty, 309 A.2d 647 (Me. 1973). After Lafferty was decided, the U.S. Supreme Court granted cert in Mullaney v. Wilbur and remanded it to the First Circuit for reconsideration in light of Lafferty. The First Circuit then accepted the Maine Court's interpretation of Maine law, reaffirmed the grant of the writ, this time relying on Winship. It then ruled, as the Supreme Court would have, that the prosecution had to bear the burden of proof on the issue of the nonexistence of mitigating provocation once that issue was fairly raised by the defense.

${ }^{46} 421$ U.S. at 691. 
passion on sudden provocation accords with due process." 47 This framing of the question reminds us why Mullaney is a beloved evidence case, one of the few High Court opinions that discusses presumptions in criminal cases, a subject left unaddressed by the Federal Rules of Evidence. $^{48}$ It also highlights how careful the Court was, and remains, in finding a balance among issues of federalism, separation of powers and fundamental fairness in criminal cases.

The Court offered a two step analysis of this procedurally framed question. Beginning with the substantive law, the Court reviewed the history of the murder/manslaughter distinction in common law. It found mitigating provocation "the most important factor in determining the degree of culpability attaching to unlawful homicide," 49 and a clear trend of requiring the prosecution to bear the burden on that fact. That analysis would have permitted the Court to answer the procedural question of Mullaney with this historically based analysis of the substantive question. The Court might have simply said that when the substantive law has historically defined the particular fact at issue as the most important factor determining the severity of the offense, it must be proven beyond a reasonable doubt. But the Court did not stop there.

The second step of the analysis then responded to a limiting argument that this historical analysis opened; even if this history was right, Winship still did not require invalidating the Maine scheme because the requirement for proof beyond a reasonable doubt only applies to facts which would wholly exonerate the defendant. On this analysis, the question of guilt or

\footnotetext{
${ }^{47} I d$. at 692.

${ }^{48}$ Article III of the Federal Rules of Evidence only addresses presumptions in civil cases. Congress rejected proposed Rule 303, which addressed presumptions in criminal cases.cite

${ }^{49} 421$ U.S. at 696. 
innocence is completely divorced from the question of degree of culpability. The suggestion was that the magnitude of being convicted of any crime, and so being stigmatized as a criminal, is so grave that the full panoply of rights must attach to that decision. On this argument, once a person is convicted, the issue of the degree of their criminal culpability is of so much less significance that fewer procedural rights should attach to that determination.

Mullaney decisively rejected that argument, although it is one that soon reemerged and loomed large in late $20^{\text {th }}$ Century sentencing. The Mullaney Court's rejection of a bright line between criminal liability and degree of culpability speaks to both the substantive law and the procedural understanding necessary to vindicate that substantive principle. The substantive criminal law point was that Anglo American criminal law takes both the guilt or innocence finding and the determination of the degree of culpability quite seriously. Our substantive law has long carefully defined crimes and ranked them; it has never simply created one broad category of malefactor and lumped all wrongdoers in together. ${ }^{50}$

The Court next reminded us that a procedural question, like the assignment of burdens, must not be allowed to swallow the substantive law principle, but rather must be interpreted to protect it. As the Court noted, if Winship were not found to limit Maine law in this case, "a State could undermine many of the interests that decision sought to protect ... redef[ining] the elements that constitute different crimes, characterizing them as factors that bear solely on the extent of punishment." ${ }^{51}$

${ }^{50}$ Although, the indeterminate sentencing of the middle of the $20^{\text {th }}$ Century and the sentencing law from the effective date of the Sentencing Reform Act to Booker both pushed quite hard on that understanding.

${ }^{51} 421$ U.S. at 698. 


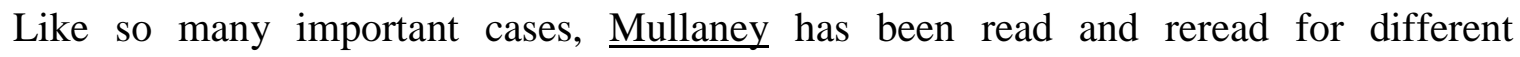
propositions. It may be most narrowly understood as holding that true presumptions can never operate in favor of the prosecution upon an element of a criminal offense. Although the case certainly stands for that proposition, that understanding of the case sheds no light on how to distinguish elements from other factors. The case may be a bit more broadly understood as holding that common law based crimes have elements so deeply rooted in our law that they cannot be altered by the legislature or the courts. As we shall see, that historically based rationale offers a way to cabin Mullaney's reach, but does not provide a broad enough understanding to answer the questions posed by subsequent cases. The case may be most broadly understood as establishing the Supreme Court's authority to review and rule upon the substantive adequacy of legislative definitions of criminal offenses and the related legislative or judicial doctrines of procedure that govern adjudication under those statutes. Although that third, and broadest reading of Mullaney is consistent with the current state of the law, there remains great uncertainty about the standards to be applied in such a review. The reach of Mullaney has ebbed and flowed over time. In reviving the broader reading of this chestnut, United States v. Booker is Mullaney's revenge.

The Court returned to the problem of the interplay between the substantive definition of a crime and procedural regulation of proof of the crime in the following term. Patterson v. New York ${ }^{52}$ addressed a very similar statute and reached a conclusion hard to square with Mullaney. Perhaps more than most Supreme Court cases involving closely related questions, Mullaney and

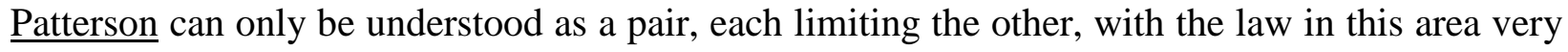

\footnotetext{
${ }^{52} 432$ U.S. 197 (1977).
} 
much dependent on which case is currently dominant. Just as Mullaney curtailed legislative and

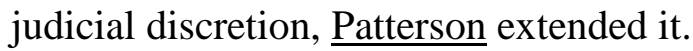

In Patterson, the Supreme Court upheld the recently re-codified and heavily Model Penal Code influenced New York homicide statute. ${ }^{53}$ New York law made all intentional killings the highest grade of non-capital murder and permitted the defendant to come forward and prove the mitigating defense of extreme emotional disturbance, which reduces the offense to the next lower grade of murder. As many have observed, there is scant difference between the statute disapproved in Mullaney and the statute approved in Patterson. Maine could not shift the burden to the defendant by requiring the defendant to prove lack of malice aforethought in order to mitigate murder to manslaughter. New York could, however, define the highest grade of murder to include all intentional murders and assign the burden of proof on the affirmative mitigating defense to the defendant. The net effect of the two statutes is the same - intentional murder is the highest grade and the defendant has the burden to prove mitigation to manslaughter. Yet, the Maine statute was held to violate the requirement that the state prove each and every element beyond a reasonable doubt to the jury, while the New York statute was upheld.

The Patterson majority squared its result with Mullaney by limiting the reach of the earlier case. ${ }^{54}$ Justice White read Mullaney for the narrow proposition that once Maine used the language "malice aforethought," it was committed to that traditional element and could not introduce a presumption in favor of the prosecution. ${ }^{55}$ In this light, the pair of cases sets very broad and historically rooted restrictions upon legislative drafting of criminal statutes. But once

\footnotetext{
${ }^{53} 432$ U.S. at 201 (ruling on New York Penal Law $§ 125.25$ (2004)).

${ }^{54}$ See 432 U.S. at 214-16.

${ }^{55} \mathrm{Id}$.
} 
Mullaney and Patterson opened the door to Supreme Court review of how legislatures define crimes, they could not be so easily cabined. Although the requirement that an element must be proven beyond a reasonable doubt to the jury seemed to provide a very broad field for legislative action, changing styles of criminal law legislation would make those boundaries much more problematic than they first appeared.

Reconciling Mullaney and Patterson by limiting Mullaney to the particulars of historically rooted, common law statutes may have resolved the immediate problem, but it was never an adequate solution. We might say that although the legislature is free to define new crimes, its options are more limited when it uses a well developed, common law scheme. A related political consideration, relevant in 1978, was the Court's reluctance to strike down a strongly Model Penal Code influenced statute during the prime years of Model Penal Code influenced re-codification of state codes. ${ }^{56}$ While each observation has force, neither brings the law to a stable rule. If Mullaney is really limited to common law statutes that have historical roots limiting the legislature, how are we to understand Patterson's language, consistent with Mullaney, that "there are obviously constitutional limits beyond which the States may not go?"57 What are those limits when the legislature drafts outside the common law tradition?

Justice Powell, in his dissent, foreshadowed this problem. ${ }^{58}$ He argued that the Patterson majority vaunted form over substance by giving the legislature the authority to redefine elements

\footnotetext{
${ }^{56}$ The majority opinion recognizes that the statute under review is part of the Model Penal Code influenced re-codification movement. 432 U.S. at 207-8, n.10 (discussing the role of affirmative defenses in the new New York Penal Law and noting that twenty-two states had already reformed their penal laws since the completion of the Model Penal Code in 1962).

${ }^{57} 432$ U.S. at 210.

${ }^{58}$ Id. at $216-232$.
} 
as affirmative defenses, eviscerating the central protection of our requirement of proof beyond a reasonable doubt, which had recently been reaffirmed by In re Winship. ${ }^{59}$ He argued for a Winship/Mullaney rule, which would examine whether the fact at issue makes a significant

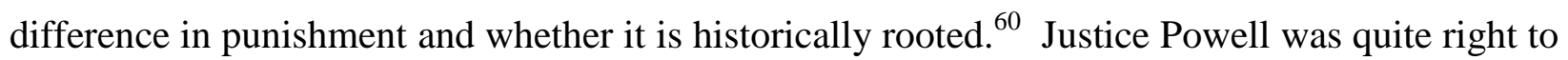
search for a rule that would ground this area in more than formal drafting requirements. While the standard for which Justice Powell argued captures the difference between Mullaney and $\underline{\text { Patterson, }}$ it offers little guidance to a criminal law expanding far beyond its historical common law roots. In the cases that followed, Justice Stevens lead the search for another way to ground the question of what is an element, and so must be proven beyond a reasonable doubt, in more than statutory drafting rules rooted in history.

The jurisprudence of the late 1970 through the late 1980s and the waning of the era of proceduralist adjudication and rehabilitative sentencing bequeathed us a vague understanding of the term "element." The law gave state legislatures great discretion in defining crimes and allocating burdens of proof. For example, state legislators could categorize all intentional murders as homicide and give defendants the burden of proof on defenses as traditional and deeply rooted as self defense. ${ }^{61}$ This broad legislative power to define crimes was counterbalanced by broad judicial sentencing discretion, and did not, at first, confront the many procedural challenges raised by mandatory sentencing schemes. That would change, but the lack of clarity, and underdevelopment of a body of doctrine defining the notion of an "element" of a criminal statute remained a central ambiguity in American sentencing law. Indeed, many of the

\footnotetext{
${ }^{59}$ Id. at $229-32$.

${ }^{60}$ Id. at $225-27$.

${ }^{61}$ Martin v. Ohio, 480 U.S. 228 (1987).
} 
sentencing law innovations of the late 1980s and 90s survived because of the Supreme Court's reluctance to elaborate a meaningful definition of "element," and instead to view this area as one of largely unfettered legislative discretion.

Even as the Court reaffirmed its broad approach to the meaning of "elements" in Martin, pressure had already begun to build as legislatures stepped away from indeterminate sentencing and rehabilitation and began their long effort to limit judicial discretion. So long as there was a clear divide between the extensive procedural protection of trial and the discretionary regime of sentencing, the model of Williams was workable, whether or not it was good policy. As legislatures began to enact mandatory sentencing statutes that tied sentencing to fact-finding, strains began to appear.

\section{Legislative Discretion Triumphant: McMillan v. Pennsylvania and Sentencing Factors}

McMillan v. Pennsylvania ${ }^{62}$ the keystone of this line of cases, involved a challenge to a Pennsylvania statute that imposed a mandatory minimum of a five year sentence on any person convicted of an enumerated felony who the sentencing judge found to have visibly carried a firearm during the commission of the crime. McMillan was the first of the Court's modern sentencing cases to address a mandatory minimum sentencing statute, a style of criminal legislation that gained popularity in the 1980s. ${ }^{63}$ Although the Court analyzed the case in doctrinal terms, as it should, the facts of the case bespeak the struggle for control of the criminal

${ }^{62} 477$ U.S. 79 (1986).

${ }^{63}$ For a discussion of mandatory minimum sentencing statutes in federal courts, and the ways they change the dynamics of criminal cases, see Ian Weinstein, Fifteen Years After the Revolution, supra note 7. 
process. The Court offered this description of the proceedings after each defendant in these consolidated cases was convicted of a qualifying underlying offense:

In each case, the Commonwealth gave notice that at sentencing it would seek to proceed under the Act. No § 9172 hearing was held, however, because each of the sentencing judges before whom petitioners appeared found the Act unconstitutional; each imposed a lesser sentence than that required by the Act. ${ }^{64}$

This restrained and technical language described a clash that would be repeated again and again. The legislature passed a statute that gave prosecutors new power over sentencing by tying punishment to the charging decision through a mandatory minimum. The sentencing judge resisted this diminution in judicial authority occasioned by the contraction of sentencing discretion. Consequently, the appellate courts had to resolve the conflict between the legislators and prosecutors on one side, and the judges on the other. McMillan sided decisively with the legislators and prosecutors, through a ruling that revisits the difficult question of the meaning of the term 'element of an offense.'

The Supreme Court ruled that the Act under review in McMillan created a sentencing factor, and did not create a new crime. ${ }^{65}$ Writing for the Court, then Justice Rehnquist acknowledged that the precedents drew no bright line rule between elements and sentencing factors. This, he told us, is a matter of "differences of degree."66 In a passage distinguishing the sentencing factors in the Pennsylvania statute from the burden shifted element in the Maine

\footnotetext{
${ }^{64} 477$ U.S. at 82 (footnote omitted).

${ }^{65} \mathrm{Id}$.

${ }^{66} I d$. at 91 .
} 
statute ruled unconstitutional in Mullaney, the Court noted:

"Section 9712 neither alters the maximum penalty for the crime committed nor creates a separate offense calling for a separate penalty; it operates solely to limit the sentencing court's discretion in selecting a penalty within the range already available to it without the special finding of visible possession of a firearm.",67

This passage became central to our understanding of the distinction between elements and sentencing factors for 18 years, from $\underline{\text { McMillan }}$ through Blakely, ${ }^{68}$ although the doctrinal tension caused by the changing pressures of onrushing events upon this vague standard became evident earlier. As unfettered judicial sentencing discretion gave way to a variety of legislatively imposed, reviewable sentencing requirements, our understanding of the phrase "a penalty within the range already available to [the court] without the special finding,"69 began to waver and change.

In one light, the essence of the shift that led to $\underline{\text { Booker was the turn from the McMillan }}$ understanding of element and maximum sentence to our current understanding. Under

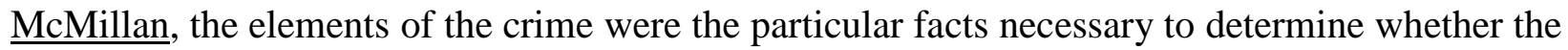
defendant was guilty and so liable for punishment up to the maximum term set by the legislative enactment that defined the crime. ${ }^{70}$ It made no difference whether the sentencing court was

${ }^{67} I d$. at 87-8 (emphasis added).

${ }^{68}$ Though, a brief period of uncertainty existed between Almendarez-Torres v. United States, 523 U.S. 224 (1998), and Jones v. United States, 526 U.S. 227 (1999).

${ }^{69} 477$ U.S. at $87-8$.

${ }^{70}$ McMillan's understanding of this question was an explicit, although unstated rejection $-26-$ 
required to give any particular sentence within any range the legislature might establish - factors that determined where in the range a defendant was actually sentenced were only sentencing factors, not elements, and were only subject to the lesser procedural restrictions of Williams and its progeny. This is the understanding so well argued by Justice O'Connor in her dissent in Apprendi v. New Jersey, 530 U.S. 466 (2000), and long articulated by Justices Breyer and Kennedy. ${ }^{71}$ Booker, as we shall see, offered a broader understanding of the maximum sentence concept, extending all rules that establish the enforceable top of the sentencing range. Of course this shift did not occur all at once, and the particular contours of the shift left McMillan standing, if greatly limited. So how did we get from $\underline{\text { McMillan to Booker? }}$

One key to the shift is found in Justice Stevens' continued critique of the application of $\underline{\text { Williams }}$ style minimalist procedural protections, appropriate to an era of rehabilitation and broad judicial discretion, to the world of enforceable Guidelines and retributivist sentencing. ${ }^{72}$

of Mullaney's dicta tying the strongest procedural protections to determinations of both guilt or innocence and the degree of the crime, and resulting punishment, for which the defendant is liable.

${ }^{71}$ A series of cases, including Jones, Apprendi, Blakely, Ring v. Arizona, 536 U.S. 584 (2002), and Booker shifted and broadened the legal understanding of the concept called "statutory maximum" in McMillan and later renamed the concept the "prescribed range of penalties." Justice Scalia, writing for the Court, told us that "statutory maximum' is the maximum sentence a judge may impose solely on the basis of the facts reflected in the jury verdict or admitted by the defendant." 121 S. Ct. 21 (2004). Rejecting the prior rule, defining the statutory maximum as the maximum term set out in the legislative enactment defining the crime, Blakely's broader definition swept enforceable sentencing guidelines into the category of elements for purposes of Winship and Patterson.

${ }^{72}$ Viewed in terms of Court politics, the shift may be seen as Justice Scalia's long term movement toward Justice Steven's position. Of course Justice Scalia developed his position in the context of orginalism and its historical perspective, while Justice Stevens remained ever sensitive to the evolving context of American criminal law and the interplay of shifting substantive law and procedure. But in the end, Justice Scalia voted with Justice Stevens in Jones, Apprendi and Blakely. 
Justice Stevens has trenchantly argued that Mullaney and Patterson, properly read, provide the tools to identify and rein in legislative excesses. In his McMillan dissent, Justice Stevens argued that there is a more fundamental distinction underneath the apparently formalist rule about presumptions in cases involving historically rooted statutes. ${ }^{73}$ He argued that the cases identify a line between aggravating and mitigating factors, capturing an essential legal and political difference between facts that increase punishment and those that mitigate punishment. ${ }^{74}$ Natural political limits exist on the legislative transformation of elements into mitigating factors, so they need not be constrained in the same way. ${ }^{75}$ Legislators are unlikely to pass extreme versions of "Patterson statutes" - statutes that broadly criminalize conduct and then burden defendants with mitigating defenses. ${ }^{76}$ He offered the example of criminalizing everyone who walks into a bank and permitting defendants to prove that they are not bank robbers. ${ }^{77}$ Such a scheme would face intense political opposition. Although his example was suggestive, recent experience shows he may have underestimated the public's willingness to accept broad criminal statutes. On the other hand, recent efforts to address corporate wrongdoing suggest that there is real political sensitivity to extending criminal sanctions to cases in which traditional markers of criminality may be less clear. Whatever the merits of his position on the dangers of overuse of mitigating factors for which the defendant has the burden, his argument on the political dangers of aggravating factors was powerful.

\footnotetext{
${ }^{73} 477$ U.S. at $99-101$.

${ }^{74}$ Id. at $100-01$.

${ }^{75} I d$. at 100-02.

${ }^{76} I d$. at 101-02.

${ }^{77} I d$. at $100-01$.
} 
Aggravating factors are quite different, he told us, because there is much less political backlash to imposing harsher penalties upon those already convicted of some crime. The experience of the last twenty years shows how politically expedient it can be to expose people convicted of any crime to horrendously harsh sentences - opposing those statutes is just being "soft on criminals." That has been our experience with sentencing factors, which have mushroomed since McMillan and unlike mitigating factors, seem to have broader political limits than many anticipated.

The experience of the late $80 \mathrm{~s}$ and $90 \mathrm{~s}$ suggests there is a real difference between aggravating and mitigating factors, as Justice Stevens argued. His dissent in McMillan foreshadowed much of the basic structure of the law today. He argued for Court scrutiny of the process of finding facts that establish the enforceable top of the sentencing range, a requirement that characterizes Apprendi and its progeny. ${ }^{78}$ His views on mitigating factors, have been somewhat oddly transformed into a distinct set of rules governing facts that establish the bottom of the sentencing range, as in $\underline{\text { Harris, }}$, an opinion from which he dissented. ${ }^{79}$ But back in 1986, Justice Stevens was still in the minority in the sentencing cases and McMillan was the law. Legislative power to define crimes and punishments, and to set the procedural requirements for criminal adjudication and sentencing, was largely unfettered by meaningful judicial review.

\section{Legislative Discretion Overreaching: Witte, Watts, Almendarez-Torres and the Apparent End of Limits on Legislative Authority to Control Substance and Procedure in}

${ }^{78} I d$. at 103 .

${ }^{79}$ See Harris v. United States, 536 U.S. 545 (2002) (holding that a statute increasing the minimum sentence after fact finding by the judge rather than by the jury does not violate a defendant's Fifth or Sixth Amendment rights). 


\section{Criminal Cases}

New questions involving procedural protections at sentencing began to come before the Court in the mid 90s, as the federal appellate courts began to sort through the issues presented by the new Federal Sentencing Guidelines, ${ }^{80}$ and the explosion of mandatory minimum and repeat offender statutes at both the federal and state levels. ${ }^{81}$ As the Court began to review the exercise of ascendant legislative authority it had encouraged, or at least countenanced in Patterson and

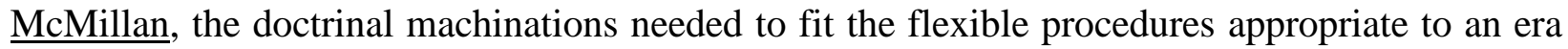
of less aggressive criminal legislation to the enactments of the late 80 s and 90 s passed from the baroque to the rococo. The devotion to legislative supremacy in criminal law, as embodied in

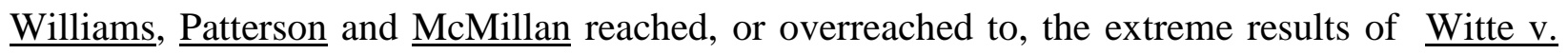
$\underline{\text { United States }},{ }^{82} \underline{\text { United States v. Watts }},{ }^{83}$ and Almendarez-Torres v. United States.${ }^{84}$

In Witte, the Court rejected a double jeopardy challenge to a federal prosecution for cocaine distribution based on conduct involving cocaine that had already been used as relevant conduct under the Guidelines to enhance the defendant's sentence ${ }^{85}$ in a prior prosecution for

${ }^{80}$ The statutory directive to draft the Guidelines is codified at 28 U.S.C. $§ 994$ (2002); The Guidelines are set out in the U. S. SENTENCING Guidelines MANUAL (2005). Issues involving the application of the Guidelines only began to come before the Court once it rejected the initial separation of powers attack on the entire system in Mistretta v. United States, 488 U.S. 361 (1989).

${ }^{81}$ For discussions of the enthusiasm for legislative sentencing enactments that both curtailed judicial discretion and increased sentence severity, see Ian Weinstein, Fifteen Years After the Federal Sentencing Revolution, supra note 7.

${ }^{82} 515$ U.S. 389 (1995).

${ }^{83} 519$ U.S. 148 (1997).

${ }^{84} 523$ U.S. 224 (1998).

${ }^{85}$ In that earlier case, the government brought a charge of marijuana distribution, although the facts involved distribution of both marijuana and cocaine. When sentencing for the $-30-$ 
marijuana distribution. ${ }^{86}$ Justice O'Connor, writing for the Court and relying upon Patterson and McMillan, argued that the sentencing court in the first case, considering the marijuana charge, was not punishing the defendant for the act of distributing cocaine, only for the charged offense of marijuana distribution. ${ }^{87}$ In the course of sentencing for distributing marijuana, the sentencing court properly considered his character as a person who had distributed substantial amounts of drugs, in deciding how to use its traditional sentencing discretion. ${ }^{88}$ Only the second prosecution punished him for distributing cocaine. To the extent that he might be punished twice in a broad sense, if not in the technical sense of punishment which limits the double jeopardy clause, any unfairness was mitigated by the Guidelines treatment of total punishment. ${ }^{89}$ Justice O'Connor drew on both the Court's double jeopardy jurisprudence for a very narrow understanding of what it means to "punish" for the instant offense and the broad McMillan understanding of what constitutes a traditional sentencing factor, going to the defendant's character.

In his dissent, Justice Stevens argued the fundamental unfairness of the result, recognized that Williams fit the era of judicial discretion, not enforceable Guidelines, continued his critique of McMillan, and took issue with the majority's application of the Guidelines. ${ }^{90}$ His argument began with the straightforward observation that the petitioner in this case was punished for

marijuana offense, the first sentencing court also considered the cocaine, as relevant conduct under Guidelines section U.S.S.G. §1B1.3, Relevant Conduct (2005).

${ }^{86} I d$.

${ }^{87}$ Id. at 396.

${ }^{88}$ Id. at 406.

${ }^{89}$ Id. at 404-06.

${ }^{90}$ Id. at 407-16. 
distributing cocaine and then put in jeopardy of punishment again for that same conduct. He first argued that only a formalistic reading of the double jeopardy clause could take this case outside its reach. $^{91}$ He argued that a better understanding of the relationship between double jeopardy and sentencing must recognize the traditional distinction between the character of the offender and the character of the offense. He noted that prior convictions considered in criminal history are clearly relevant to the defendant's character and clearly fall under the line of cases carving out recidivism as a traditional sentencing factor under $\underline{\text { McMillan }} .{ }^{92}$ But relevant conduct goes to the character of the offense. In addition, he made the explicit connection between changes in sentencing law and the need to reexamine procedural principles when he noted:

[I]n traditional sentencing regimes, it is impossible to determine for what purpose the sentencer has relied on the relevant conduct. In my view, ... the Court's failure to recognize the change in sentencing practices caused by the Guidelines, cause it to overlook an important and obvious violation of the Double Jeopardy Clause. $^{93}$

Justice Stevens continued, arguing that the limited procedural protections of Williams were set in the context of information about the character of the accused, not the character of the offense, and did not work in this new era in which statutory provisions make such a strong and explicit connection between the character of the offense and the severity of the punishment.

The dissent then granted that McMillan was the governing law, but that the even in that context, the structure of the Guidelines cut against the majority's approach. ${ }^{94}$ He noted that

\footnotetext{
${ }^{91}$ Id. at 410.

${ }^{92}$ Id. at 409-10.

${ }^{93} I d$. at 412.

${ }^{94}$ Id. at 409-12.
} 
under the Guidelines, relevant conduct is an offense characteristic, not an offender characteristic. ${ }^{95}$ Thus, not only as a conceptual matter, but as a matter of the actual Guidelines rules, relevant conduct is an offense characteristic under the Guidelines and the defendant was being punished for his conduct, not his character, in the first offense, triggering double jeopardy protection. $^{96}$

Although Witte is a double jeopardy case and draws on that line of cases, it is also an important sentencing case. The Court relied, as it must have, on a broad reading of McMillan to reach this result. The result in Witte is only doctrinally consistent if the court continues "rejecting the claim that whenever a State links the 'severity of punishment' to 'the presence or absence of an identifiable fact' the State must prove that fact beyond a reasonable doubt."97 Only an explicit (and hard to defend) uncoupling of the guilt/innocent line from the determination of the severity of the crime and sentence supports the Court's claim that, in any useful sense, the defendant in Witte was not twice punished for the same conduct. If the government had been required to twice prove, beyond a reasonable doubt, that Witte had committed the conduct at issue, it is difficult to see how the double jeopardy claim could have been denied in any but the most unconvincing manner.

The Court's commitment to the broad reading of the Williams message of judicial sentencing, and the very real friction between that idea and more than ten years of active legislative efforts to cabin that discretion and compel judges to impose uniform and severe

\footnotetext{
${ }^{95} I d$. at $410-11$.

${ }^{96} I d$. at 411.

${ }^{97} I d$. at 401 (citations omited).
} 
sentences was well illustrated by the Court's decision in United States v. Watts. ${ }^{98}$ Watts was one of a pair of cases from the Ninth Circuit in which the defendant went to trial on multiple counts and was convicted on some counts but acquitted on others. In both cases, the sentencing judge considered the conduct underlying the acquittals, as relevant conduct under the Sentencing Guidelines. Finding that the conduct could be considered as relevant conduct under the Guidelines, ${ }^{99}$ and was proven by a preponderance of the evidence, ${ }^{100}$ both sentencing courts enhanced the sentences for the convictions to a term within the statutory maximum for the counts of conviction but higher than the sentence that would have been imposed without inclusion of the relevant conduct.

In a per curiam opinion granting certiorari and reversing without full briefing, the Court sided with all of the other circuit courts and reversed the Ninth Circuit in holding that the sentencing courts had acted properly in these two cases. The Court treated as well settled the principle that the procedures governing a judge's choice of a particular sentence, so long as it does not exceed the statutory maximum set by the statute defining the offense, are quite separate from and much more relaxed than those that govern the determination of the defendant's guilt. The first paragraph of the opinion closed with, "[b]ecause the panels' holdings conflict with the clear implication of 18 U.S.C. $§ 3161$, the Sentencing Guidelines, and this Court's decisions,

${ }^{98} 519$ U.S. 148 (1997).

${ }^{99}$ " Conduct that is not formally charged or is not an element of the offense of conviction may enter into the applicable guidelines range." U.S.S.G. \$1B1.3 comment., backg'd. With respect to certain offenses, such as Putra's drug conviction, USSG $\S 1 B 1.3(a)(2)$ requires the sentencing court to consider "all act and omissions that were part of the same course of conduct or common scheme or plan as the offense of conviction." Id. at 153.

${ }^{100} I d$. at 149 (noting that an acquittal does preclude relitigating the same issue in a subsequent proceeding governed by a lower standard of proof). 
particularly Witte v. United States, 515 U.S. 389, 132 L. Ed 2d 351, 115 S. Ct. 2199 (1995), we grant the petition and reverse in both cases." ${ }^{101}$ Walking a path now clear, the Court cited 18 U.S.C. $§ 3161$, the statute imposing "no limitation" on the information to be considered at sentencing. ${ }^{102}$

Justice Stevens, joined in dissent by Justice Kennedy, again noted that Williams style procedural sentencing discretion means something completely different in the era of enforceable Guidelines. Making an argument which would need a few more years maturing before garnering a majority on the Court, Justice Stevens noted that while any information may be considered in the exercise of discretion, the Guidelines left only a very narrow range of discretion in the decision of what sentence to impose within the applicable Guideline range. In contrast, all of the other judicial sentencing decisions determining the applicable sentence did not deal with discretionary choices governed by the principles of $\S 3161$ and Williams. ${ }^{103}$ Those decisions are not left to the judge's discretion, but are governed by enforceable law and are much closer to the line drawn in Mullaney. Mullaney will resurface in this debate to remind us that the substantive criminal law, with all of its strong procedural protections, was long concerned with not just whether a person was guilty of an offense, but also being correct about what particular offense it was so that the correct degree of stigma and punishment would attach.

The Court returned to this question, in a different dress, in Almendarez-Torres v. United $\underline{\text { States }},{ }^{104}$ the last case in which a majority of the Court accepted the full force of McMillan. ${ }^{105}$

\footnotetext{
${ }^{101} I d$. at 149.

${ }^{102} I d$. (citing $§ 3161$ ).

${ }^{103} I d$. at 162 .

${ }^{104} 523$ U.S. 224 (1998).
} 
Almendarez-Torres involved a challenge to the illegal reentry statute, which imposed a two year maximum on a person who reentered the country without special permission after deportation, except that any person deported after conviction of an aggravated felony was subject to a twenty year mandatory minimum. ${ }^{106}$ The defendant was charged with illegal reentry in an indictment which did not charge that the defendant had been deported after conviction of an aggravated felony. ${ }^{107}$ The Pre-sentence Report noted the defendant's eligibility for an enhanced sentence. The defendant objected that the statutory maximum was limited to two years, given the language of the indictment, the facts to which he admitted and the omission of his waiver of his right to proof beyond a reasonable doubt on the fact of his previous conviction of an aggravated felony. The judge imposed a sentence of eighty-five months. ${ }^{108}$ The defendant appealed and the Court affirmed the sentence. ${ }^{109}$

Justice Breyer, writing for the Court, rejected the defendant's argument, finding that the aggravated felony requirement was a sentencing factor, not an element. ${ }^{110}$ The Court began its analysis by trying to determine Congress' intent, staying true to McMillan's central teaching that

${ }^{105}$ The continued vitality of Almendarez-Torres is in doubt. The reach of the case was narrowed by Shepard v. United States, 125 S.Ct. 1254 (2005) (strictly limiting the information judges may consider in determining whether a prior conviction is sufficient to enhance a sentence). Justice Thomas has also repeatedly observed that since he announced he has changed his view and would overrule Almendarez-Torres, a majority of the Court no longer supports the rule. See his concurrence in Shepard. See id. at 1264.

${ }^{106} 523$ U.S. at 224 (reviewing 8 U.S.C. $§ 1326(b)(2)$ ).

${ }^{107}$ Id. at $226-27$.

${ }^{108}$ Id. at 227.

${ }^{109} I d$. at 248.

${ }^{110}$ Id. at $226-27$. 
the legislature is free to define crimes as it chooses within very broad constitutional limits. ${ }^{111}$ After close analysis of the statutory language, the Court concluded that Congress intended the section to operate as a sentencing factor, not an element. ${ }^{112}$ After finding that the legislature intended to create a sentencing enhancement and not an element, the Court went on to consider whether there was a constitutional infirmity in that choice.

The Court first considered whether Mullaney and Patterson limit legislative power in this case and the opinion emphasized how weak the limiting principle of Mullaney had become when it observed:

At most, petitioner might read all these cases, taken together, for the broad proposition that sometimes the Constitution does require (though sometimes it does not require) the State to treat a sentencing factor as an element. But we do not see how they can help petitioner more than that. ${ }^{113}$

The Court then considered McMillan, the case "upon which petitioner must rely."114 Applying the five factor test of McMillan, and emphasizing that recidivism is the classic sentencing factor, the Court noted that this statute is just like the statute in McMillan in four of the five dimensions discussed in the earlier case. ${ }^{115}$ As in McMillan, i) there was no express violation of the limits set out in Patterson, as the government did not enjoy a presumption of a long established and central element of a common law crime, ii) the defendant did not face a differential in sentencing ranging from a fine to life in prison, as was the case with the Maine

\footnotetext{
${ }^{111} I d$. at 228-35.

${ }^{112}$ Id. at 235 .

${ }^{113} I d$. at 242 (emphasis in the original).

${ }^{114}$ Id.

${ }^{115}$ Id. at $242-46$.
} 
statute rejected in Mullaney, iii) the statute did not create a separate offense and, iv) the statute "gave no impression" that it was intended to make the enhancement the tail that wagged the dog, but only gave precision to a traditional sentencing factor. ${ }^{116}$

The high water mark of the strong uncoupling of liability from severity and the strongest application of Williams to the changed world of McMillan and legislative assertion of power comes in the analysis of the fifth McMillan factor in Almendarez-Torrez as the Court stepped over the statutory maximum line, the last clear limiting principle. The Court concluded that although the statute in this case did raise the maximum sentence specified by the legislative enactment defining the crime, they have not and would not adopt a bright line rule "that any significant increase in a statutory maximum sentence would trigger a Constitutional "elements" requirement." ${ }^{117}$ The majority's treatment of the statutory maximum in Almendarez-Torres marked the apogee of Patterson's legislative discretion model. The analysis revolved around discerning legislative intent. The Court discussed the idea of constitutional limitations on legislative power late, little and lightly. Perhaps those who can read tea leaves could see significance in the fact that Justice Scalia authored a dissent arguing for a pullback from the Court's support for virtually unfettered legislative discretion. Justice Scalia first argued that $\underline{\text { McMillan should be read to set a real and substantial limit on legislative discretion, requiring that }}$

${ }^{116}$ Id. at $243-46$.

${ }^{117} I d$. at 247 . The opinion went on to note that it would be anomalous to establish a bright line rule about the statutory maximum in light of the fact that a judge could constitutionally make factual findings rendering a defendant eligible for a death sentence. Id. at 247. Of course that rule would not survive the great shift that was about to occur, as Apprendi was followed by Ring. 
facts resulting in a sentence above the statutory maximum be treated as elements. ${ }^{118}$ The dissent then went on to critique the notion that recidivism is different from other sentencing factors and only then addresses the question of statutory interpretation. It would not be too long before a majority of the Court would be willing to impose real limitations upon legislative discretion to define crimes, reasserting the role of the jury that undergirds a broader reading of Mullaney and reopening space for judicial discretion in the era of detailed legislative criminal statutes.

\section{Mullaney's Revenge: Jones, Apprendi and the Reassertion of Limitations on the Legislature}

Unless you stand far out on the mud flats at First Encounter Beach on Cape Cod, it can be very hard to identify the moment when the tide starts to run in again. And even when you can see it running in, some of the tidal pools continue draining for a while. Sometime between the Court's decision in Witte, when the tide was running out fast against limits on legislative control of criminal law, and Jones, when the tide was clearly running back, there was a shift. Looking back, it seems that a bit of distance from the crack epidemic of the early 90s and the real and significant decrease in crime in America coupled with a growing sense that new policing and security approaches really worked combined to create space in public debate for examination of questions like the growing evidence of wrongful convictions in the death penalty arena and the human and financial costs of harsh, mandatory sentencing. Few of us saw it as it was happening, but the one way ratchet slowed, even if it did not reverse.

${ }^{118} I d$. at 253. Importantly, Justice Scalia carefully distinguished mandatory minimums from maximums. 
The significance of the next case in this line, Jones v. United States, ${ }^{119}$ is obvious in hindsight. However, at the time, it seemed to many to be just a small step back on the long march to legislative discretion to define crimes and set punishments with ever increasing specificity. Jones involved a challenge to the federal carjacking statute, ${ }^{120}$ which carried a maximum sentence of fifteen years in the ordinary case, but permitted a sentence up to twentyfive years if there was a finding of serious bodily injury. Jones was tried on an indictment that did not plead serious bodily injury, convicted by a jury and then sentenced to twenty-five years after the trial judge found the requisite enhancing fact of injury, by a preponderance of the evidence. $^{121}$

This sentence could have been affirmed, perhaps per curiam, with reliance on Witte,

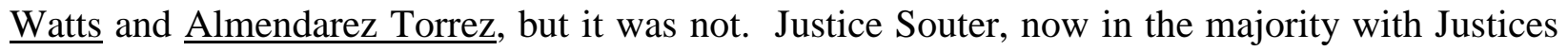
Scalia, Ginsburg and Stevens, with the other dissenters in Almendarez-Torres, joined here by Justice Thomas, turns first to the question of legislative intent. Although the Court found that mode of analysis sufficient to decide Almendarez-Torrez, here it is inconclusive. ${ }^{122}$ The majority expressed an inclination toward the view that Congress intended to define a separate crime and so made serious bodily injury an element, rather than a sentencing factor. But the Court recognized "the possibility of the other view," 123 and in the face of that uncertainty, read the statute to avoid declaring it unconstitutional. Although the Court might have stopped there

\footnotetext{
${ }^{119} 526$ U.S. 227 (1999).

${ }^{120} 18$ U.S.C. $\S 2119$.

${ }^{121} 526$ U.S. at $230-31$.

${ }^{122} I d$. at 233.

${ }^{123}$ Id.
} 
and treated $\underline{\text { Almendarez-Torres }}$ and $\underline{\text { Jones }}$ as only a pair of constitutional doubt cases, presenting

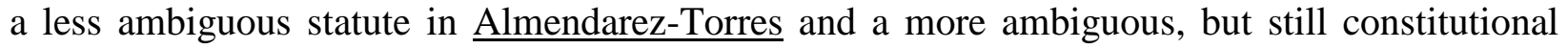
statute in Jones, it did not. ${ }^{124}$ This apparent deference to the legislature set up the larger constitutional question of what limits the Court would impose as the majority went on to breathe new life into Mullaney.

Taking a strikingly different analytic tack from the mid 90s cases discussed above, the $\underline{\text { Jones }}$ opinion went on to discuss the fundamental division of authority between judge and jury under the Sixth Amendment, revived the McMillan formulation of the statutory maximum as the limit above which a mere sentencing factor may not further enhance a sentence and clearly limited $\underline{\text { Almendarez-Torres }}$ to cases in which recidivism is the enhancing factor. ${ }^{125}$ The holding that the car jacking statute created two separate crimes and that serious bodily injury must be pled and proven to the jury proved the turning point in the Supreme Court's contemporary sentencing cases.

As is so often the case as the Court takes incremental steps, the complicated relationships among the boundaries of legislative power, judicial power, prosecutorial power and the role of the jury are only partially explored in Jones. The analysis of the jury's historical role and the explicit focus on balance between judge and jury marked an important shift in analysis, away from statutory construction and discussions of legislative intent and toward the constitutional limits on legislative discretion. That shift in analysis would become more pronounced in

\footnotetext{
${ }^{124}$ See id. at $248-49$.

${ }^{125}$ See id. at 251-52.
} 
$\underline{\text { Apprendi and Blakely. }}{ }^{126}$ What remained unstated in $\underline{\text { Jones, }}$, but surfaced quite clearly in Blakely, was discussion of the twenty year shift from indeterminate sentencing to detailed sentencing statutes and Guidelines. In a system dominated by guilty pleas, the apparent doctrinal shift of authority from judge to jury (expanding the range of elements and so apparently diminishing the judicial role), was really a shift in power back to judges and away from a twenty year rise in legislative and prosecutorial power to set punishment.

Justice Kennedy's dissent in Jones gestured in the direction of the systemic impact and potential disruption to which the underlying reasoning of $\underline{\text { Jones }}$ could, and eventually did, lead. ${ }^{127}$ First analyzing the statutory language for evidence of Congressional intent, the dissent argued that the statute creates only a sentencing factor. ${ }^{128}$ The dissent then went on to argue that Almendarez-Torres should have been understood as reaching more broadly and cementing the broad view of legislative discretion to define crimes. ${ }^{129}$ Raising the flag of formalism first flown in this debate by Justice Powell in his dissent in Patterson, Justice Kennedy noted that the majority would have had Congress simply raise the statutory maximum to life, changing a few

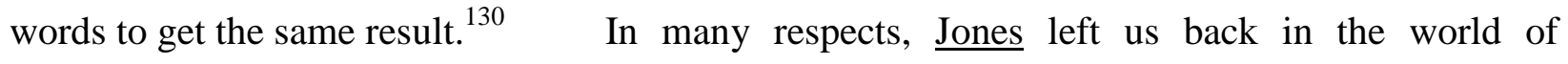
$\underline{\text { Mullaney }}$ and Patterson. After $\underline{\text { Patterson, }}$, it seemed there were some limits to legislative authority to define crimes. It appeared that those powers were broad, but the contours of the discretion were uncertain. McMillan gave us broad discretion, seemingly limited by the

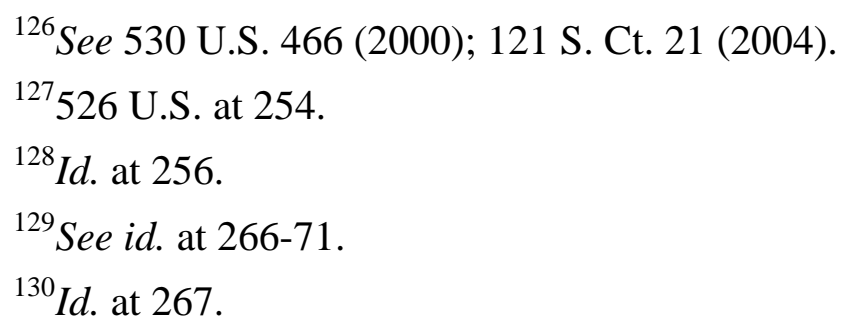


statutory maximum in the legislative enactment defining the crime. Then Almendarez-Torres suggested that even the statutory maximum was not a clear limit. These were the doctrinal underpinnings of detailed statutory sentencing provisions and enforceable Guidelines.

$\underline{\text { Jones }}$ signaled a change in direction, but left open the real possibility that the Court would continue to set very broad limits and might leave much of contemporary sentencing undisturbed. The Court was willing to impose some limits on legislative discretion to define

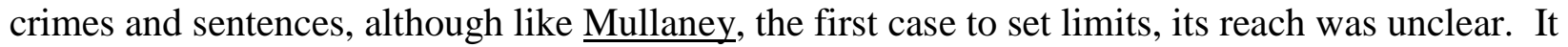
seemed possible that $\underline{\text { Jones }}$ would have its Patterson, a follow up case that would limit Jones to its very particular setting and reaffirm the late $20^{\text {th }}$ Century sentencing world of Williams style minimalist procedural requirements in the era of enforceable Guidelines. Instead, we got Apprendi.

Justice Stevens, writing for the majority, positioned Apprendi as flowing from and foreshadowed by Jones. ${ }^{131}$ Apprendi involved the New Jersey assault statute, which carried a ten year statutory maximum, but permitted a sentence of up to twenty years if the assault was racially motivated. ${ }^{132}$ The judge sentenced the defendant to twelve years, although the finding of racial bias was made by the judge, under a preponderance of the evidence standard. ${ }^{133}$ The Court offered an extended, historically based discussion of the Sixth Amendment right to a jury trial and emphasized the special role statutory maxima play in our system. ${ }^{134}$ The opinion then

${ }^{131} 530$ U.S. at 476. Apprendi also flowed from Justice Stevens' dissents in McMillan, $\underline{\text { Witte }}$ and Watts and the clear echoes of those dissents in Justice Scalia's dissent in AlmendarezTorres.

${ }^{132} I d$. at 468-69 (referring to N.J. Stat Ann. § 2C:4-3(e) (West 2000)).

${ }^{133}$ Id. at 471 .

${ }^{134} I d$. at $476-83$. 
set out a rule that did not use the language "statutory maximum," but the broader phrase "prescribed range of penalties." The Court told us:

... [with the prior offense exception] we endorse the statement of the rule set forth in the concurring opinion[s] [of] . . . [Jones]. "It is unconstitutional for a legislature to remove from the jury the assessment of facts that increase the prescribed range of penalties to which a criminal defendant is exposed. It is equally clear that such facts must be established by proof beyond a reasonable doubt.",135

The battle lines have now shifted. The question was no longer whether statutory maxima offered a bright line rule, but whether other kinds of limits, most notably Guidelines, fell within the ambit of "the prescribed range of penalties."

Justice O'Connor's dissent took on the historical analysis of the majority and argued that the rule announced in Apprendi effectively overrules McMillan, without admitting that it did so or justifying the departure from stare decisis. ${ }^{136}$ Although one may quibble with the characterization that McMillan was overruled, no doubt exists that Apprendi was profoundly unsympathetic to the McMillan approach, which eschewed bright line rules in this area and supported broad legislative discretion to define crimes and punishment. Justice Breyer made the point more plainly in his dissent, arguing that Apprendi upset the settled understanding on the division of sentencing authority and cast grave doubt on modern sentencing. ${ }^{137}$ His dissent also asked whether juries can engage in the detailed fact-finding required by enforceable Guidelines, raising questions about two parts of the triangular relationship among juries, judges and

\footnotetext{
${ }^{135}$ Id. at 490.

${ }^{136} I d$. at 476-85.

${ }^{137}$ Id. at 564-66.
} 
legislatures (and those legislative surrogates in this context, the prosecutors). ${ }^{138}$

\section{One Step Back and the Final Leap Forward: $\underline{\text { Harris, }} \underline{\text { Blakely and Booker }}$}

Although Apprendi was clearly a very significant case, it was followed by an opinion that could have limited it, as $\underline{\text { Patterson limited Mullaney. Harris v. United States }}{ }^{139}$ posed a challenge to the mandatory sentencing provision of 18 U.S.C. $\$ 924(c)$, which imposes a minimum seven year term upon anyone convicted of a crime of violence or a narcotics trafficking offense who brandishes a weapon during the commission of that offense. The defendant argued that the statute created a separate crime which was not submitted to the jury for proof beyond a reasonable doubt and thus violated Jones. ${ }^{140}$ The defendant also argued that the statute increased the prescribed range of penalties and violated Apprendi. ${ }^{141}$

The majority, made up of the Jones dissenters and Justice Scalia, breathed new life into McMillan, which also involved a mandatory minimum sentence for use of a gun in the commission of another crime. In a decision that may be read as carefully distinguishing the precedents and applying stare decisis, or as using a bit of formalism to revive the letter if not the spirit of a discredited case, the Court ruled that section 924(c) was a sentencing factor under McMillan, not an element under Apprendi. ${ }^{142}$ The doctrinal key to $\underline{\text { Harris }}$ is the distinction between juries finding facts that set the maximum penalty, and judges finding facts that establish

\footnotetext{
${ }^{138} I d$. at 557.

${ }^{139} 536$ U.S. 545 (2002).

${ }^{140} I d$. at 551.

${ }^{141} I d$.

${ }^{142} I d$. at 556-57.
} 
the bottom of a sentencing range.

Justice Thomas, in dissent and joined by the remaining three of the Jones majority, Justices Stevens, Souter and Ginsburg, argued that the logic and language of Apprendi cannot and should not be squared with McMillan. ${ }^{143}$ He relied, with some justification, on the argument that the language "facts that increase the prescribed range of penalties," embraces mandatory minimums, as well as the maximum, ${ }^{144}$ as a range of five years to life is, in common understanding, an increase in the range of penalties over a range of zero years to life. Justice Thomas notes that "before today, no one seriously believed that the Court's earlier decision in $\underline{\text { McMillan could coexist with the logical implications of the Court's later decisions in Apprendi }}$ and Jones." ${ }^{\prime 145}$ But $\underline{\text { Harris }}$ revived the possibility that legislative discretion to define crimes and to allocate and limit judicial sentencing authority, sufficient to sustain most enforceable guidelines systems, could survive. After $\underline{\text { Harris, }}$ it seemed possible that the Court would walk the line, requiring that statutory maximum altering facts go to juries and all, or some subset of other enhancing facts, could remain with the judge. But Blakely v. Washington erased many of those questions.

Famously, at least within the world of sentencing law, Blakely brought the top of the range in enforceable sentencing guidelines systems within the ambit of $\underline{\text { Jones }}$ and Apprendi. Once the door closed on the meaning and scope of the phrase "facts that increase the prescribed range of penalties," the major hope to save the Federal Guidelines was the argument that they were not statutes, but some other form of law that did not fall within the rule first promulgated

\footnotetext{
${ }^{143} I d$. at 572.

${ }^{144} I d$. at 578.

${ }^{145} I d$. at 582 .
} 
by Mullaney. But that argument did not garner five votes on the Supreme Court. Booker followed directly from Blakely and, by that point, the interesting and hard questions were remedial, not doctrinal.

\section{Conclusion}

The road from Mullaney to Booker took us far into the land of unlimited legislative discretion and back. It started in an era characterized by fewer, less specific criminal statutes which relied upon judicial discretion and indeterminate sentencing to apply those broader rules to the vast array of cases that came before the courts. Procedural protections mattered less in that system because sentences turned on individual judgements, not the application of rules. The system had little need to examine the limits of legislative power, as the legislature was not inclined to approach, let alone push upon, the limits it had long observed.

By the late 1980s, the whole interdependent system began to shift dramatically. As legislators began to define crimes and set punishment with ever greater specificity, sentencing procedures began to matter a great deal and the bounds of legislative and judicial power became contested. Although the doctrinal questions played out in the right to a jury trial, our reliance upon guilty pleas has turned jury power into judicial power, at least for now. The politicization of criminal justice in the 1980s and the strong assertion of legislative dominance in criminal justice that developed in response to that politicization were the underlying forces that pushed 
these issues forward. In what may be a healthy exercise in correcting power imbalances among the branches of our government, the Court circled back around to renewed concern with the limits of legislative power as the issues took on a very different cast in the world of mandatory minimums and enforceable Guidelines.

At each turn in the direction of the Court's limit setting on legislative discretion, $\underline{\text { Patterson }}$ and $\underline{\text { Jones, }}$ the dissent argued that either the majority's failure to limit legislative authority or the majority's excessive limitation upon legislative authority is a retreat into mere formalism - the legislature can always find a way to write the statute to achieve its desired result within the bounds of the Court's requirement. This captures the current reality. Whether we think about "topless guidelines" or a system of very lengthy and detailed statutes setting out a wide array of mandatory sentences for very specific offenses, drafting alternatives exist to return us to much of pre-Booker sentencing in the post- $\underline{\text { Booker }}$ worlds.

Predictions about the future of criminal sentencing in America have lately been frequent and frequently wrong. As a theoretical matter, there is great appeal in the call for the Supreme Court to engage in more regulation of the substantive criminal law. As William Stuntz has argued, the Court could construct a system of procedural limits with real bite on substantive criminal statutes, creating an updated version of common-law court lawmaking and couple it with revived judicial sentencing authority. ${ }^{146}$ This would insulate our criminal law from the danger of politicization of criminal justice, which I have argued is at the root of the stresses and

${ }^{146}$ See Stuntz, supra note 3 (suggesting Constitutional regulation of the substantive criminal law as one way to escape the problems of over-criminalization and excessive prosecutorial power brought on by the politicization of American criminal justice policy). 
excesses of the last twenty years.

Short of that major change, perhaps we must recognize that there is very likely to be a degree of formalism in any solution the Court offers to these problems. In our system of multiple criminal law codes and coordinate branches of government, it may well be impossible to find a substantive solution that will provide stable lines defining the reach of each branch, especially assuming each branch continues to push on the line. Perhaps Justice Stevens was right to look to self limiting principles in the long term politics of criminal law. In his analysis of the difference between aggravating and mitigating factors, he noted the natural limits on turning elements into mitigating factors - at some point too much innocent conduct is swept in and people are unwilling to have many defendants forced to prove their innocence.

But aggravators are different, as their harm is limited to an already despised class, convicted criminals. While Justice Stevens is right and the Court must step in to protect the rights of defendants, it may also be true that even aggravating factors have an upper political limit. At some point, the creation of too many aggravating factors creates clear enough substantive injustice to merit public attention. The continued development of enhanced and mandatory penalties has become a clear cause of injustice in America as the public learns of more and more sentences that simply do not fit the crime.

The history of this period is still to be lived and written. But if it turns out that the tide of sentence severity and politicization of criminal justice has turned, then we will have reached the political limits of enhancing sentences through legislative domination of our criminal law. That would offer the best hope of a more workable and stable long term solution. If each branch and player in our system would stop trying to expand his or her power by pressing aggressively on 
the edges of the law, the fundamental limits of the doctrines would not matter so much. We would stop running up against the limits of the law - after all the law itself cannot make us good, it can only help us to be good if we are so inclined. 